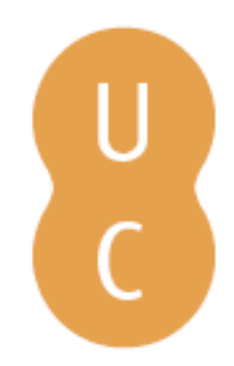

\title{
pommalina
}

\section{Pyroclimatic classification of Mediterranean and mountain landscapes of south- eastern France}

Autor(es): $\quad$ Fréjaville, Thibaut; Curt, Thomas

Publicado por: Imprensa da Universidade de Coimbra

URL

persistente: URI:http://hdl.handle.net/10316.2/34348

DOI: $\quad$ DOI:http://dx.doi.org/10.14195/978-989-26-0884-6_136

Accessed : $\quad$ 26-Apr-2023 00:56:18

A navegação consulta e descarregamento dos títulos inseridos nas Bibliotecas Digitais UC Digitalis, UC Pombalina e UC Impactum, pressupõem a aceitação plena e sem reservas dos Termos e Condições de Uso destas Bibliotecas Digitais, disponíveis em https://digitalis.uc.pt/pt-pt/termos.

Conforme exposto nos referidos Termos e Condições de Uso, o descarregamento de títulos de acesso restrito requer uma licença válida de autorização devendo o utilizador aceder ao(s) documento(s) a partir de um endereço de IP da instituição detentora da supramencionada licença.

Ao utilizador é apenas permitido o descarregamento para uso pessoal, pelo que o emprego do(s) título(s) descarregado(s) para outro fim, designadamente comercial, carece de autorização do respetivo autor ou editor da obra.

Na medida em que todas as obras da UC Digitalis se encontram protegidas pelo Código do Direito de Autor e Direitos Conexos e demais legislação aplicável, toda a cópia, parcial ou total, deste documento, nos casos em que é legalmente admitida, deverá conter ou fazer-se acompanhar por este aviso.

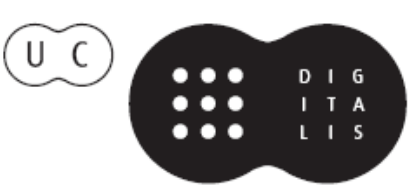




\section{ADVANCES IN}

Forest Fire

\section{RESEARCH}

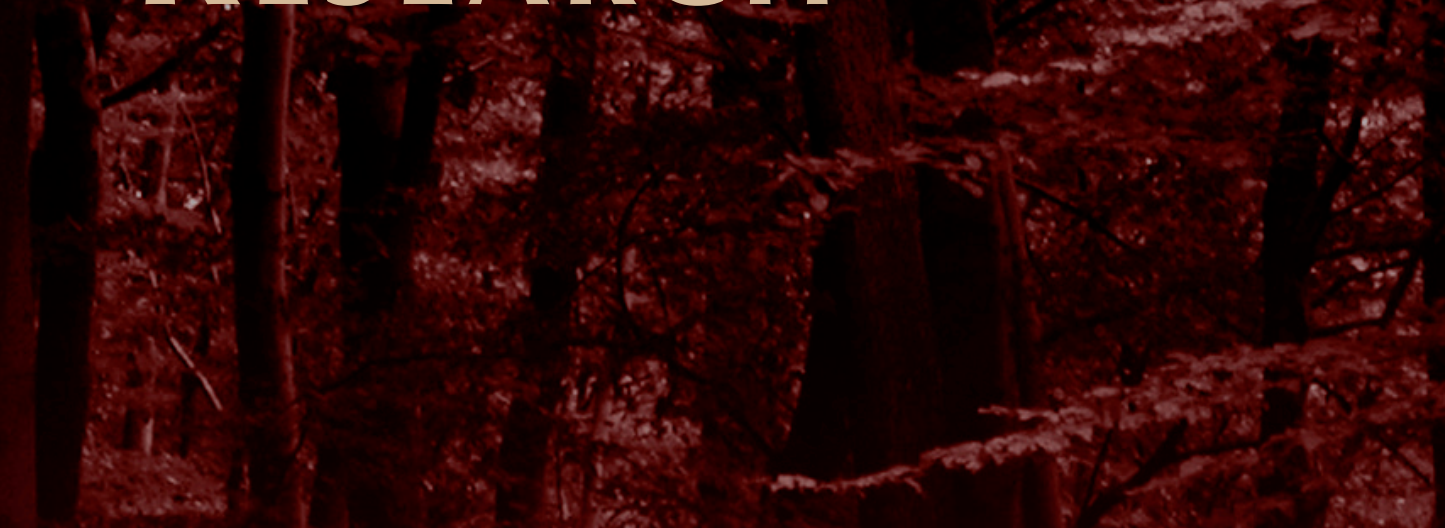

\section{DOMINGOS XAVIER VIEGAS}

\section{EDITOR}




\title{
Pyroclimatic classification of Mediterranean and mountain landscapes of south-eastern France
}

\author{
Thibaut Fréjaville, Thomas Curt \\ IRSTEA, UR EMAX, 3275 route Cézanne, F-13185 Aix en Provence, France. \\ thibaut.frejaville@gmail.com, thomas.curt@irstea.fr
}

\begin{abstract}
Fire risk is expected to increase in the Mediterranean Basin like in many areas worldwide. Climate is likely the main driver of fire activity by conditioning fuel dryness and fire weather. However fire-climate relationships are conditioned by other environmental dimensions like fuel structure (composition and spatial arrangement of flammable vegetation) and human activities. Therefore assessing how climate controls fire activity in heavily anthropized landscapes like European Mediterranean regions requires to design analyses in appropriate geographic units to encompass the dominant fire drivers. We aimed to assess how spatiotemporal patterns of both fire activity and climate structured south-eastern France into homogeneous geographic unit which we defined as 'pyroclimatic' regions.

We performed a pyroclimatic classification of Mediterranean and mountain areas of south-eastern France at 2 $\mathrm{km}$ resolution from the national fire database and daily atmospheric parameters over 1973-2009. This classification was based on multidimensional and clustering analyses. South-eastern France is characterized by three main 'pyroclimatic' regions and ten sub-regions from high fire-prone maritime mountains to moderate fire-prone hot lowlands and low fire-prone inner moist mountains. These geographic units are discriminated from each other by fire activity, fire seasonality, fire weather and their recent evolution.

We demonstrated that fire activity and fire weather of south-eastern France are highly dynamic in space and time. Characterizing pyroclimatic regions offers new regional perspectives of fire management and policy because two areas having similar fire weather, fire regime and recent temporal trends would benefit for specific attention.
\end{abstract}

Keywords: pyrogeography, climate change, fire danger, fire activity, fire density, burned area, Mediterranean ecosystems, mountain.

\section{Introduction}

Future changes of fire activity would be highly heterogeneous in space and time (Flannigan et al. 2009; Moritz et al. 2012). Spatial patterns of fire activity are governed by environmental gradients of climate, vegetation and ignition which drive pyrogeography worldwide (sensu Krawchuk et al. 2009). In this sense, authors argued that global changes are likely to have different effects on fire regimes respective to the predominant drivers (Bradstock, 2010; Krawchuk \& Moritz, 2010). Climate is likely the main driver of fires because it controls both fire weather and fuel moisture (e.g. Flannigan et al. 2000) such as fuel amount (Bond and Keeley 2005). Otherwise, human influence on current and past fires has been emphasized as a key process (Bowman et al. 2011). In particular, the fire-climate relationship at a regional scale should be offset by temporal changes in land use and or fire management policies (Mouillot and Field 2005; Marlon et al. 2008). Therefore, it appears that no description or prediction of climate effects on wildfires makes sense without reference to particular climatic, ecological and human contexts. Human influence on fire activity has already been highlighted in Mediterranean areas through transformation of land cover and ignition potential (Loepfe et al. 2012). On the other hand, the northern Mediterranean Basin are facing an increasing fire risk with ongoing climate change (Bedia et al. 2013) and because fires are expected to be primarily limited by weather conditions in these areas (Batllori et al. 2013). We aimed to assess the diversity of French Mediterranean 'pyroclimates', i.e. regions having similar fire regime, similar climate, and similar recent trends of both. We expect that partitioning south-eastern France into pyroclimates will allow testing the variability in local fire drivers 
because fire activity varies strongly across the study area (Figure 1). Moreover characterizing 'pyroclimates' has management implications since two areas having similar fire weather, fire regime and temporal trends would benefit from similar fire management and policy. So we aimed to assess the spatiotemporal patterns of fire weather and fire regime across south-eastern France and test how they are distributed into homogeneous geographic units, i.e. pyroclimatic regions.

\section{Methods}

Fire regime and fire weather of south-eastern France were quantified over 1973-2009 at two kilometre resolution from the national fire georeferenced database (Prométhée 2011) and daily atmospheric parameters of Safran reanalysis system (Vidal et al. 2010).

Fire regime was quantified from $2 * 2 \mathrm{~km}$ aggregates of i) fire season length (number of days between the first and the last fire of the year), ii) yearly and seasonal fire occurrence (fire density) and iii) yearly and seasonal cumulated size of fires which ignited in a given pixel. As we aim to capture regional variation in fire regime, we applied an inverse distance weighting function to smooth fire statistics over a larger moving window $(30 \mathrm{~km})$. A spatial smoothing of fire metrics allowed us to emphasize their deterministic part by reducing the stochasticity inherent to the fire process. Moreover, as fire regime may need more than four decades to be assessed in the less fire-prone regions, we expanded the spatial search range of fire occurrence in a given pixel from two (pixel resolution) to ten kilometres (moving window of $5 \mathrm{~km}$ radius). Fire danger was assessed from components of the Canadian Fire Weather Index System which rate the initiation, spread and control of forest fires. Fire weather index (FWI) and its drought components (FFMC, DMC, DC) were computed from the equations of Van Wagner and Pickett (1985) based on daily noon parameters (Van Wagner 1987). The use of instantaneous conditions (12h GMT) instead of daily means was recently pointed out to get reliable estimates of mean and extreme conditions of fire danger (Herrera et al. 2013). Climate patterns were assessed from monthly and yearly averages of temperature and precipitation whose computations are based on daily mean temperature and cumulated rainfall respectively. All these indices were downscaled from height to one kilometre resolution by the help of regional statistical modelling following standard procedures (Zimmermann and Kienast 2009; Zimmermann et al. 2013). Specifically downscaling procedure was based on vertical gradient modelling per homogeneous climatic regions ('symposium', Vidal et al., 2010) and anomaly inference. Fire danger and bioclimatic indices were first computed before downscaling and then aggregated to $2 * 2 \mathrm{~km}$ (fire database resolution). Temporal trends over 1973-2009 were quantified for all fire regime variables and downscaled climatic indices by the statistics of a modified Mann-Kendall trend test (Hamed and Ramachandra Rao 1998).

We carried out the pyroclimatic classification of south-eastern France by ordination and clustering analyses on four subsets: i) fire regime metrics, ii) climate (fire danger and bioclimatic indices) and iii-iv) their past temporal trends. First, we independently synthesized each of the four subsets from Principal Components Analyses (PCA) with backward selection procedure. Backward selection was applied to remove the least contributory variables in order to synthesize the multidimensional variability of fire, climate and temporal trends into a reduced number of gradients (i.e., principal components). We prior standardized seasonal fire and climatic variables by pixel (0-1) to limit autocorrelation with annual means and to study the seasonal distribution of them among pyroclimatic regions. Secondly, we performed a hierarchical agglomerative clustering (HAC) on principal components based on a Euclidean distance matrix and the Ward criterion (Ward 1963). The number of group was given by the Calinski-Harabasz criterion (Caliński and Harabasz 1974) applied on an independent k-means clustering with Monte Carlo simulations (Makarenkov and Legendre 2001). All analyses and calculations were performed on R environment (R Core Team 2013), with the help of the 'fume' package for FWI calculations and trend tests (Santander Meteorology Group 2012). 


\section{Results and discussion}

Average patterns over 1973-2009 of annual fire density and size show a high variability of fire activity across South-eastern France (Figure 1). We find the most fire prone areas in the eastern Mediterranean coast where from west to east, calcareous and siliceous Provence, the maritime pre-Alps and Corsica have experienced both the highest density of fires and the highest burned area. In the western coast, we find several fire-prone islands around major cities with high burned areas and moderate fire density. A third area with high density and cumulated size of fires was found in north-western inlands (Ardeche plateau). Elevated mountain areas in Eastern Pyrenees, Cevennes and Southern Alps (from west to east) are less fire-prone. These spatial gradients of fire activity are partly related to fire weather ones, depicted by the drought code (DC) and the fire weather index (FWI) of the Canadian Fire Weather Index System (Figure 1). Annual extremes $\left(95^{\text {th }}\right.$ percentile) of DC and FWI are maximal in the western Mediterranean coast and minimal in elevated mountain areas which are relatively characterized by high versus low fire activity respectively.
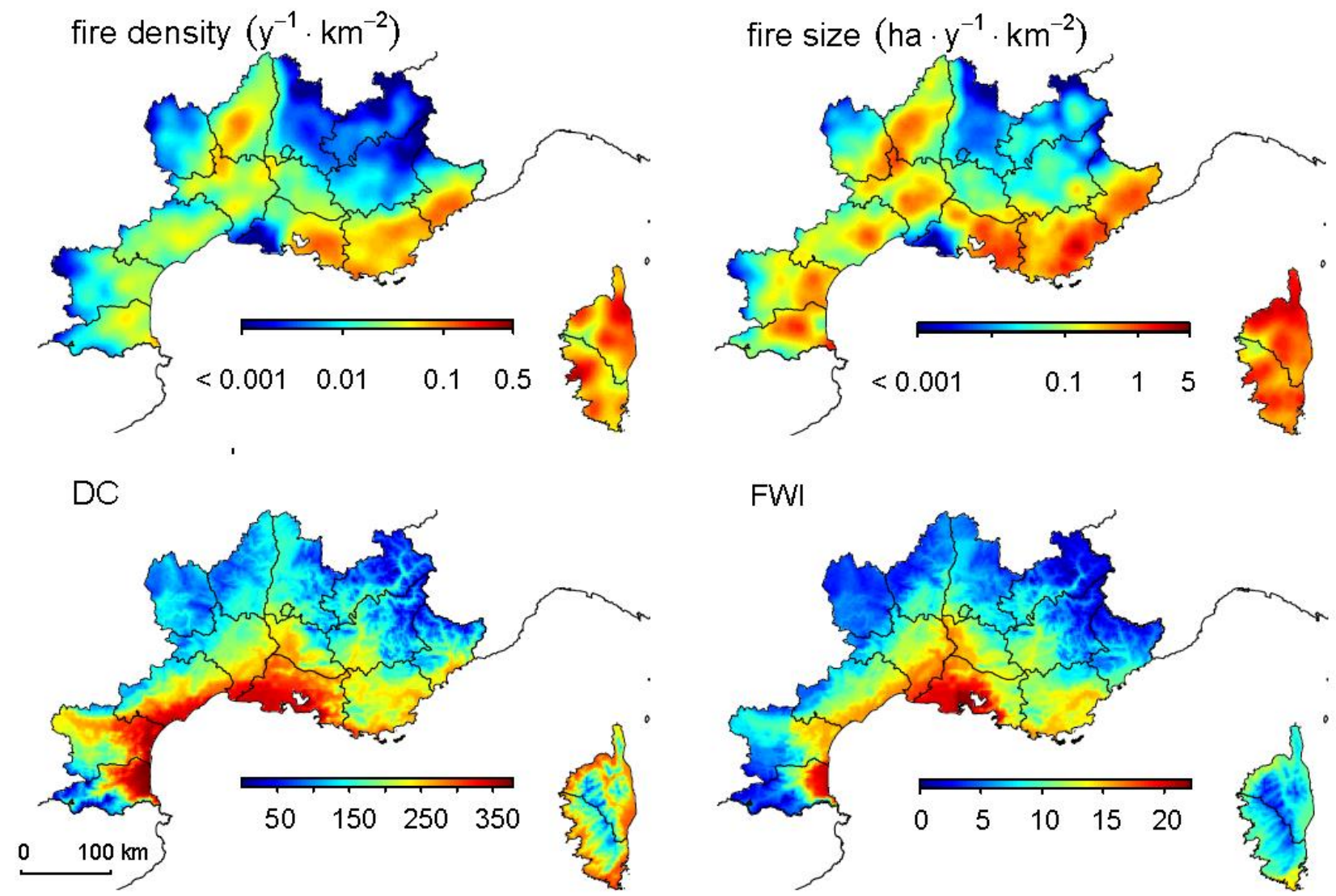

Figure 1. Spatial patterns of annual fire density, fire size, Drought Code and Fire Weather Index in the 15 departments of south-eastern France (1973-2009 averages). Fire metrics were smoothed by an inverse distance weighting function on a $30 \mathrm{~km}$ moving window (log-scale). Fire size represents here the cumulative size of fires which ignited in a given square kilometre per year. Maps of fire weather indices have been computed from extreme annual values $\left(95^{\text {th }}\right.$ percentile).

By taking into account fire activity, fire weather and their temporal trends over 1973-2009, clustering analyses indicated that south-eastern France is divided into three pyroclimatic regions and 10 subregions (Figure 2). These regions constitute specific combinations of climate and fire regime from the highest fire-prone maritime mountains (Corsica and maritime pre-Alps, $\mathrm{PCr}-1$ ) to high fire-prone Mediterranean-climate lowlands (Mediterranean coast and Rhone valley, $\mathrm{PCr}-2$ ) and low fire-prone moist and cold inner mountains (eastern Pyrenees, Cevennes and southern Alps, PCr-3). 


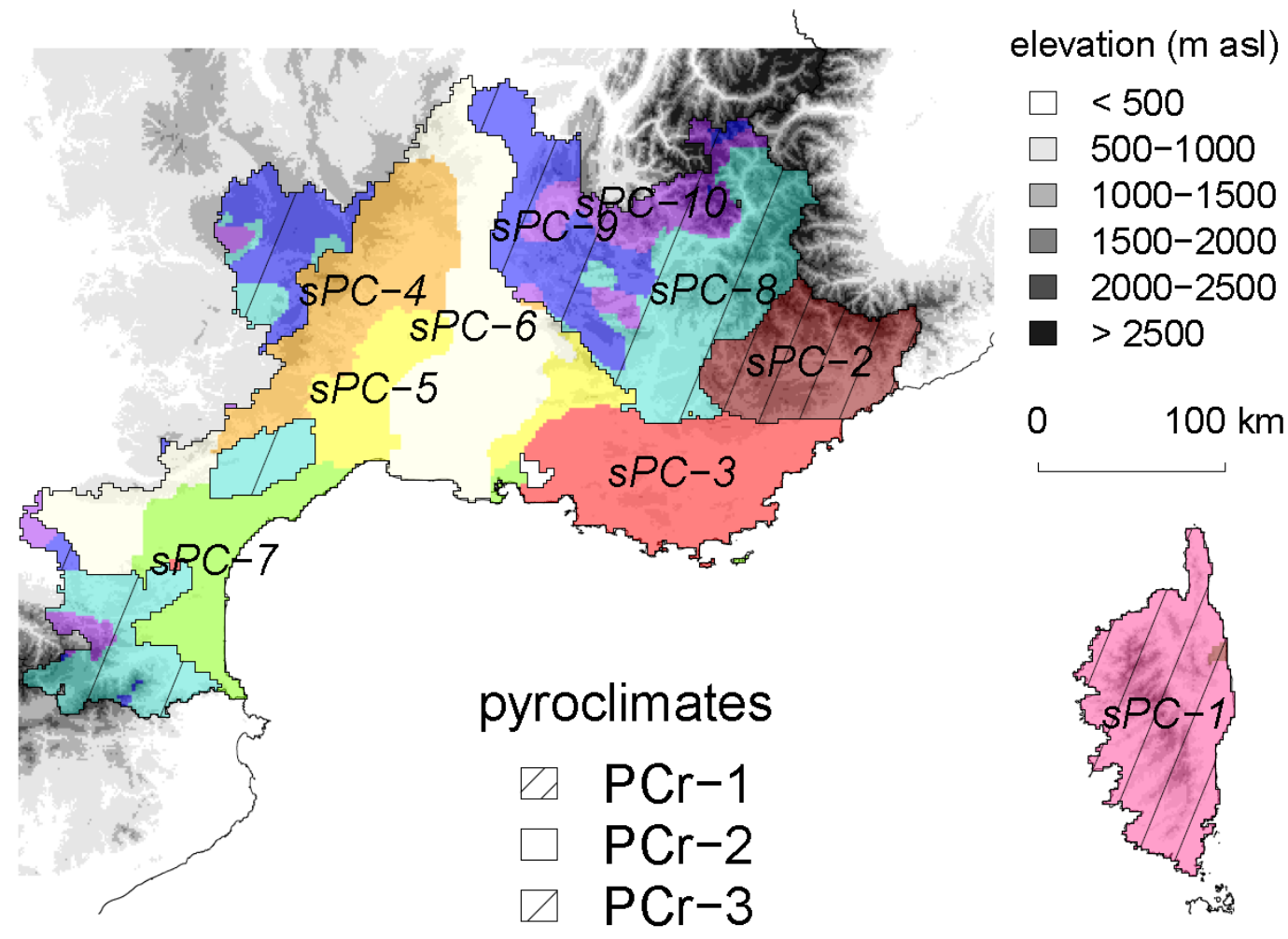

Figure 2. Pyroclimatic regions of south-eastern France. Pyroclimatic regions $(P C r)$ were subdivided into 10 subpyroclimates (sPC). Sub-regions $S P C-1$ and 2 belong to pyroclimate PCr-1; sPC-2 to sPC-7 belong to PCr-2 and sPC8 to SPC-10 belong to PCr-3. See Method section for details on pyroclimate partitioning.
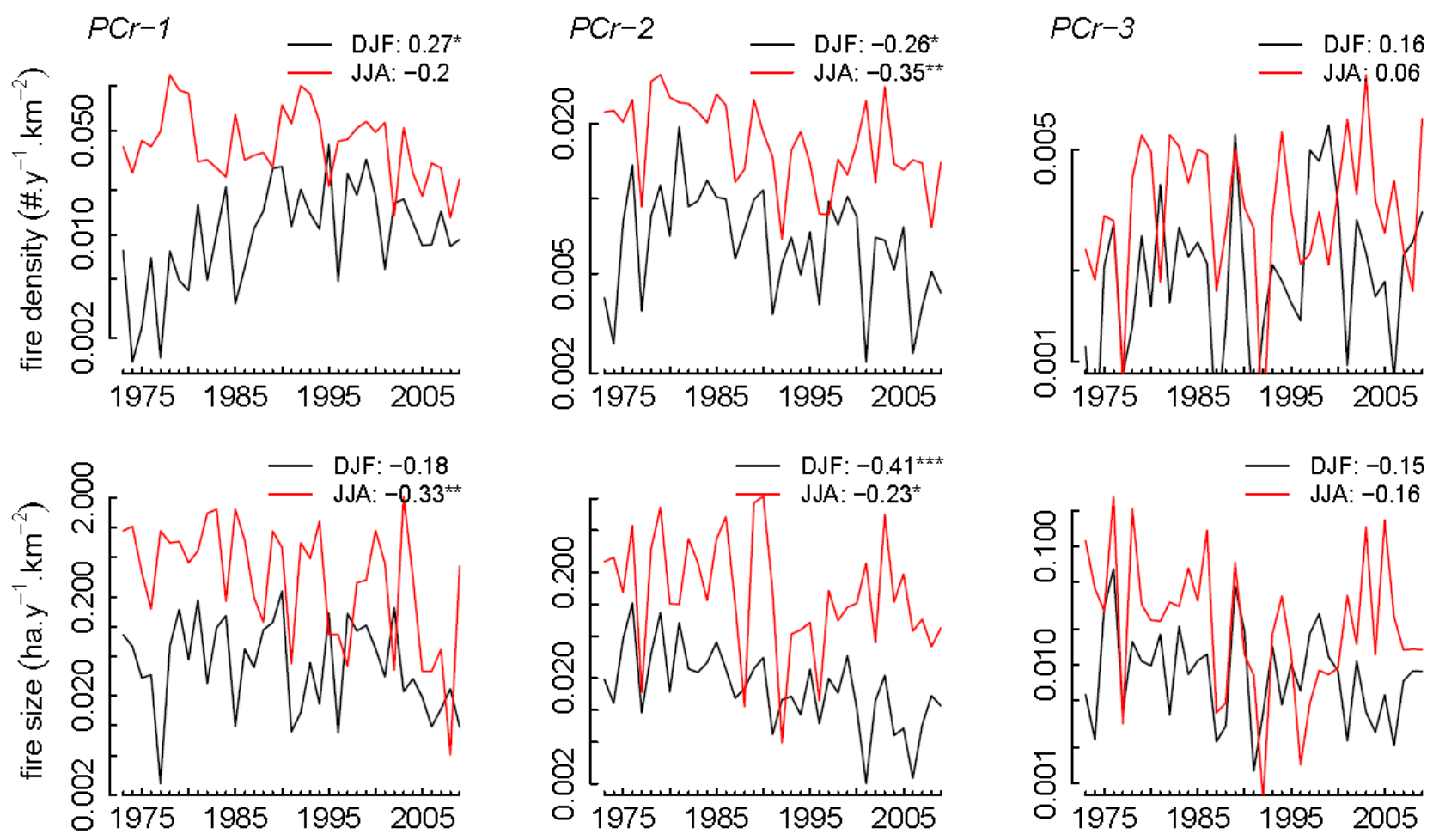

Figure 3. Averaged temporal trends (1973-2009) of winter (DJF) and summer (JJA) fire density and fire size (logscale) within the three pyroclimatic regions. Correlation coefficient $(t)$ and significance $(* p<0.05, * * p<0.01, * * * p$ $<0.001)$ are presented for Mann-Kendall modified trend tests. Fire size represents here the cumulative size of fires which ignited in a given square kilometre per year. 
Fire danger is the highest in PCr- 2 and the lowest in PCr-3 in respect to annual mean and $95^{\text {th }}$ percentile of FWI and DC (Figure 1). Trend tests over the four past decades indicated that mean fire danger has significantly increased in all three regions, depicted by yearly mean FWI (tau $>0.42, p<0.01$ ). Fire danger extreme conditions have followed the same increasing trend $\left(95^{\text {th }}\right.$ percentile FWI: tau $>0.39$, $\mathrm{p}<0.05$ ). These findings corroborate previous study in Mediterranean areas (Carvalho et al. 2008; Bedia et al. 2013). Otherwise fire activity is largely seasonally restricted with one peak in winter and one in summer. The two most fire-prone regions PCr-1 and PCr-3 are characterized by a predominant fire activity in summer compared to PCr-3 (69, 73 and $45 \%$ of annual burned area, respectively). On the contrary, winter burned area is higher in annual proportion within the less fire-prone elevatedmountain region PCr-3 (30 \% against $19 \%$ and $10 \%$ in $\mathrm{PCr}-1$ and $\mathrm{PCr}-2$ respectively). In these more weather-limiting landscapes spring fires contribute to $18 \%$ of annual burned area, whereas autumn fires are poorly contributing with less than $7 \%$ of annual burned area whatever the pyroclimatic region. 1973-2009 trends of seasonal fire activity showed contrasted patterns too (Figure 3). Indeed winter fire density has increased in PCr-1 ( $<<0.05)$, decreased in PCr-2 $(\mathrm{p}<0.05)$ while both fire density and size have not significantly changed in winter and in summer across PCr-3 ( $p>0.05)$. Overall in the two most fire-prone regions, both summer fire density as winter and summer fire size have decreased these past decades (Figure 3) with higher significant trends for the hotter and dryer pyroclimatic region $(\mathrm{PCr}-2, \mathrm{p}<0.05)$.

We demonstrated that south-eastern France has contrasted geographic units, i.e. pyroclimatic regions, which revealed differences in both spatial and temporal patterns of fire and climate. This classification would offer new regional perspectives in fire management policy by defining regional affinities in both fire weather and fire regime dynamics. In the heavily anthropized landscapes of south-eastern France, fire activity appear likely more heterogeneous in space and time than in other Mediterranean areas where burned area has increased since the seventies (Pausas 2004; Carvalho et al. 2008). Indeed we found that fire density and fire size have increased in some regions and decreased in others with season-specific trends. These findings point out that changes in fire activity may strongly differ between closed regions without a priori evident climatic explanation. This may involve a stronger expression of climatic-independent altering dimensions such as fire suppression strategies (Mouillot and Field 2005; Brotons et al. 2013) or land cover transformation (Loepfe et al. 2012). This study highlights that the predominance of fire drivers among climate, vegetation and human factors may likely differ across small spatial ranges and may counteract the effects of climate change on future regional fire activity.

\section{Acknowledgements}

Financial support was provided by the FUME Project under the European Union's Seventh Framework Programme (FP7/2007-2013) and by grants from the National Research Institute of Science and Technology for Environment and Agriculture (IRSTEA) to TF. Authors acknowledge the national meteorological agency Météo-France and Jean-Philippe Vidal for providing climate data. We also acknowledge the public institutions that have fueled the fire national database Prométhée and Christophe Bouillon for help in formatting this database.

\section{References}

Batllori E, Parisien M-A, Krawchuk MA, Moritz MA (2013) Climate change-induced shifts in fire for Mediterranean ecosystems. Global Ecology and Biogeography 22(10), 1118-1129. doi:10.1111/geb.12065.

Bedia J, Herrera S, Camia A, Moreno JM, Gutiérrez JM (2013) Forest fire danger projections in the Mediterranean using ENSEMBLES regional climate change scenarios. Climatic Change 1-15. doi:10.1007/s10584-013-1005-z. 
Bond WJ, Keeley JE (2005) Fire as a global 'herbivore': the ecology and evolution of flammable ecosystems. Trends in Ecology \& Evolution 20(7), 387-394.

Bowman DMJS, Balch J, Artaxo P, Bond WJ, Cochrane MA, D'Antonio CM, DeFries R, Johnston FH, Keeley JE, Krawchuk MA, Kull CA, Mack M, Moritz MA, Pyne S, Roos CI, Scott AC, Sodhi NS, Swetnam TW (2011) The human dimension of fire regimes on Earth. Journal of Biogeography 38(12), 2223-2236. doi:10.1111/j.1365-2699.2011.02595.x.

Brotons L, Aquilué N, de Cáceres M, Fortin M-J, Fall A (2013) How Fire History, Fire Suppression Practices and Climate Change Affect Wildfire Regimes in Mediterranean Landscapes. PLoS ONE 8(5), e62392. doi:10.1371/journal.pone.0062392.

Caliński T, Harabasz J (1974) A dendrite method for cluster analysis. Communications in Statistics 3(1), 1-27. doi:10.1080/03610927408827101.

Carvalho A, Flannigan MD, Logan K, Miranda AI, Borrego C (2008) Fire activity in Portugal and its relationship to weather and the Canadian Fire Weather Index System. International Journal of Wildland Fire 17(3), 328-338.

Flannigan MD, Krawchuk MA, de Groot WJ, Wotton BM, Gowman LM (2009) Implications of changing climate for global wildland fire. International Journal of Wildland Fire 18(5), 483-507.

Flannigan MD, Stocks BJ, Wotton BM (2000) Climate change and forest fires. Science of the total environment 262(3), 221-229.

Hamed KH, Ramachandra Rao A (1998) A modified Mann-Kendall trend test for autocorrelated data. Journal of Hydrology 204(1), 182-196.

Herrera S, Bedia J, Gutiérrez JM, Fernández J, Moreno JM (2013) On the projection of future fire danger conditions with various instantaneous/mean-daily data sources. Climatic Change 118(3-4), 827-840. doi:10.1007/s10584-012-0667-2.

Krawchuk MA, Moritz MA, Parisien M-A, Van Dorn J, Hayhoe K (2009) Global Pyrogeography: the Current and Future Distribution of Wildfire. PLoS ONE 4(4), e5102.

Loepfe L, Martinez-Vilalta J, Piñol J (2012) Management alternatives to offset climate change effects on Mediterranean fire regimes in NE Spain. Climatic Change 115(3-4), 693-707. doi:10.1007/s10584-012-0488-3.

Makarenkov V, Legendre P (2001) Optimal Variable Weighting for Ultrametric and Additive Trees and K-means Partitioning: Methods and Software. Journal of Classification 18(2), 245-271. doi:10.1007/s00357-001-0018-x.

Marlon JR, Bartlein PJ, Carcaillet C, Gavin DG, Harrison SP, Higuera PE, Joos F, Power MJ, Prentice IC (2008) Climate and human influences on global biomass burning over the past two millennia. Nature Geoscience 1(10), 697-702.

Moritz MA, Parisien M-A, Batllori E, Krawchuk MA, Van Dorn J, Ganz DJ, Hayhoe K (2012) Climate change and disruptions to global fire activity. Ecosphere 3(6), art49. doi:10.1890/ES11-00345.1.

Mouillot F, Field CB (2005) Fire history and the global carbon budget: a $1^{\circ} \times 1^{\circ}$ fire history reconstruction for the 20th century. Global Change Biology 11(3), 398-420. doi:10.1111/j.13652486.2005.00920.x.

Pausas JG (2004) Changes in Fire and Climate in the Eastern Iberian Peninsula (Mediterranean Basin). Climatic Change 63(3), 337-350. doi:10.1023/B:CLIM.0000018508.94901.9c.

Prométhée (2011). "La banque de données sur les incendies de forêts en région Méditerranéenne en France." http://www.promethee.com/.

R Core Team (2013) R: A language and environment for statistical computing. R Foundation for Statistical Computing (Vienna, Austria) URL http://www.R-project.org/.

Santander Meteorology Group (2012) fume: FUME package. R package version 1.0. URL http://CRAN.R-project.org/package=fume.

Vidal J, Martin E, Franchistéguy L, Baillon M, Soubeyroux J (2010) A 50-year high-resolution atmospheric reanalysis over France with the Safran system. International Journal of Climatology 30(11), 1627-1644. doi:10.1002/joc.2003. 
Van Wagner CE (1987) Development and structure of the Canadian Forest Fire Weather Index System. Canadian Forestry Service, Forestry Technical Report 35. (Ottawa, ON)

Van Wagner CE, Pickett TL (1985) Equations and FORTRAN program for the Canadian Forest Fire Weather Index System. Canadian Forestry Service, Forestry Technical Report 33. (Ottawa, ON)

Zimmermann NE, Gebetsroither E, Zuger J, Schmatz D, Psomas A (2013) Future Climate of the European Alps. 'Management Strategies to Adapt Alpine Space Forests to Climate Change Risks'. (Ed G Cerbu)(InTech)

Zimmermann NE, Kienast F (2009) Predictive mapping of alpine grasslands in Switzerland: species versus community approach. Journal of Vegetation Science 10(4), 469-482. 